\title{
GEOSPATIAL ANALYSIS OF LAND COVER CHANGES IN BAČKA FROM 1990 TO 2018
}

\author{
Miloš Ostojić ${ }^{A}$, Renata Fekete ${ }^{A}$, Minučer MesarošA \\ Received: September 4, 2019 | Accepted: December 22, 2019 \\ DOI: $10.5937 /$ ZbDght19020970
}

\begin{abstract}
The area of Bačka is located in northwestern part of Serbia. Although it is predominantly a lowland area, Bačka is characterized by several relief forms that differ in altitude, geological and pedological composition, hydrological conditions, various anthropogenic influences and, therefore, land cover. For the study period, sociogeographical characteristics are more important than natural ones. Human has largely influenced the spatial changes in this region, first of all by forming agricultural areas in all suitable places, then by expanding urban areas caused by population growth, and also by woodcutting and pond formation. Research is focused on the period since there is more accurate and comparable data on the land cover of Serbia in order to detect and analyze the changes faithfully. This paper uses geospatial data from Corine Land Cover (CLC) database that shows the state of land cover from 1990 to 2018 for most of Europe. The aim of this paper is to recognize spatial changes in these data using geographic information system (GIS) and to identify the factors that caused these changes. Motive for this research is still a small number of papers on this topic in Serbia.
\end{abstract}

Keywords: Bačka, land cover, GIS, Corine, change detection

\section{INTRODUCTION}

The history of studying spatial changes through remote sensing begins with the launch of the first satellites for Earth observation in the second half of the 1960s, first of all Landsat program. Today we also use other sources, such as archival satellite images of the Corona program, which was a secret military program in the second half of the 1960s.

Over time, methods and techniques for monitoring spatial changes have evolved and refined, but basic methods are still used today because of their simplicity and fast performance. At the same time, the theoretical part of science was developing. The great inter-

A University of Novi Sad, Faculty of Sciences, Department of Geography, Tourism and Hotel Management, Trg Dositeja Obradovića 3, 21000 Novi Sad, Serbia; contact: milosostojicgo1@gmail.com 
est in the topic of monitoring spatial change on Earth can be explained by the increasing attention to the effects of global climate and anthropogenic changes (Théau, 2012).

The latest geospatial studies on the subject of surface changes are concerned with the application of remote sensing and modern methods of processing and analysis of geospatial data that open the possibility of studying surface changes globally with very high spatial and temporal resolution (Hansen et al., 2013).

Theoretical approach to this scientific discipline in the $21^{\text {st }}$ century was largely contributed by Burgi, Hersperger and Scheneeberger (2004) trying to define the driving forces of landscape change, then Lambin and Geist (2006) who dealt with the causes of global environmental changes, i.e. land use and land cover changes, as well as the local processes that cause these changes. Plieninger et al. (2016) have dealt with the major driving forces of spatial changes in Europe. Some of the scientists who have dealt with this subject in Serbia are Samardžić-Petrović et al. (2015), and Potić et al. (2017). Stankov et al. (2016) were explored surface change issues and their impact on tourism, and Jovanović et al. (2015) applying remote sensing to changes in land cover in Zlatibor.

There are four geomorphological units in Bačka: Subotica sandy terrain, loess plateaus, upper Pleistocene (Diluvial) terraces and alluvial plains of the Danube and Tisa rivers (Bukurov, 1975; Popov et al., 2012). These units differ from each other in elevation, with the consequence that this, at first glance monotonous area, has as many as 22 categories of land cover.

The data sources for this research were downloaded from the Copernicus website in the form of a Corine Land Cover (CLC) database that shows status of land cover of the 1990, 2000, 2006, 2012 and 2018 for most European countries. Using this database we get exact and comparable data with the same resolution and quality.

The aim of the paper is to identify the main tendencies of the changes that happened on this territory during the investigated period, their interpretation and analysis using GIS methods, as well as to identify and explain the factors that caused these changes. Finally, the paper will attempt to answer the question of possible changes in land cover in Bačka in the coming decades.

\section{MATERIAL AND METHODS}

\section{Study area}

Bačka is located in the southern part of the Pannonian Plain and in the northwestern part of the region of Vojvodina and Serbia. It is bounded by the river Danube in the west and south, the river Tisa in the east and the border with Hungary in the north. Considering the natural northern border of the Balkan Peninsula on the Sava and Danube rivers, Bačka belongs to the region of Central Europe. Its landscape is relatively monotonous. However, Bačka is not an ideal plain because it contains several geomorphological entities that differ from each other in time and manner of origin, as well as the forces that created them. Almost all of the territory of Bačka is covered with extremely fertile land and 
has been an attractive destination for settlements since ancient times (Bukurov, 1975). The area of Bačka according to Davidović et al. (2005) is $9224 \mathrm{~km}^{2}$, according to Kicošev et al. (2006) this number is $8671 \mathrm{~km}^{2}$. If the Srem parts of the Novi Sad and Bačka Palanka municipalities are annexed to Bačka, then its surface is $8956 \mathrm{~km}^{2}$ (Bukurov, 1978; Subin, 1979). Area obtained by vectorization of its surface following the border with Hungary and the central parts of the Danube and Tisa river flows in MGI Balkans 7 projection is $8927.9 \mathrm{~km}^{2}$ and this surface is used to analyze the surface changes in this paper.

\section{Definition and study of spatial changes}

Landscape is the primary sphere in which the combined effects of society and nature become visible. As society and nature are dynamic and changeable, change is an inevitable feature of landscapes. Today's landscape is the result of natural processes and human influences in the past (Burgi, 2004). Théau (2012) defines the detection of spatial changes as the process of noticing differences in state of an object or occurrence through its observations at different times. The primary sources of data used in such studies are mostly digital, raster satellite and aerial images. However, data in analogue form in the form of topographic maps are also used. Vector, economic and historical data may be used to a lesser extent.

Remote sensing allows collecting big amounts of data by monitoring of large areas, and its use enables us to obtain an accurate picture of the condition of the land surface (Grujić et al. 2017). Satellite imagery provides the highest coverage of the investigated territory in terms of spatial, temporal and spectral resolution (Théau 2012). Images from satellites have a wide application for identification and detection of objects, phenomena and changes on the surface of the Earth (Popović, Jovanović, 2017). Today they are a free source of geospatial information and can be downloaded in high resolution.

Burgi et al. (2004) identified 5 major drivers of spatial change: socioeconomic, political, technological, natural and cultural.

Spatial changes can most easily be observed by analyzing one of the land cover databases. These bases are generated by exhaustive analysis and processing of satellite images from Landsat, Modis, Sentinel or other satellites. For the purposes of this paper, the Copernicus Corine Land Cover program database, which was implemented in the European countries for 1990, 2000, 2006, 2012 and 2018, was used.

\section{Corine land cover}

The land cover mapping project under this program aims to provide, through the Corine database, quality localized geographical information on land cover in Europe. The goal of Corine database is to provide a list of land surface features, primarily for the proper management of the environment (Heyman et al., 1994). With the development of technology, each subsequent recording was more modern. The project of the first Corine recording in 1990 took a whole 10 years, while it took a year and a half to create the last Corine program from 2018. Number of countries implementing this program increased with each successive program, with 38 countries participating in the program 
since 2006. Although the technology has advanced, therefore, the possibility of more detailed and better mapping of land cover, in order to compare them across all five implemented mapping programs, the minimum mapping unit (MMU) is 25 hectares for polygons, and the minimum line thickness for line entities is 100 meters. For the spatial change database, the MMU is 5 hectares (https://land.copernicus.eu).

According to Corine nomenclature, land cover classes are grouped into three levels. There are 44 classes on the third, most detailed level of the Corine classification, on the second 15, while the first level is made of five classes: Artificial surfaces, agricultural areas, forests and semi-natural areas, wetlands, and water bodies (Nestorov, Protić, 2009).

In Bačka, 26 classes of land cover out of 44 existing under this program occur through the five implemented Corine programs. Of these, four classes occur in some years but not all, such as airports, landfills, construction sites, and dunes, beaches and sands. Other 22 classes appear in all investigated years.

In software ArcMap 10.2., maps of the land cover in Bačka were visualized, then the areas affected by the change of land cover class were detected on them. After that, it was observed in which classes the most changes occurs, i.e. within which types of land cover the decrease occurred and within which types of surfaces increase occurred.

\section{RESULTS AND DISSCUSION}

\section{Artificial surfaces}

Of the 26 classes that occur in Bačka through these programs, as many as 11 represent artificial surfaces, i.e. Class 1, namely: Continuous urban fabric with code 111, discontinuous urban fabric (112), industrial or commercial units (121), road and rail networks and associated land (122), port areas (123), airports (124), mineral extraction sites (131), dump sites (132), construction sites (133), green urban areas (141), and sport and leisure facilities (142). Of these categories, discontinuous urban fabric accounts for the largest distribution, accounting for $85 \%$ of this class in 2018 , up to $86.9 \%$ in 2000 . The second category by area is industrial or commercial units, which occupy from $9.4 \%$ to $11.1 \%$ of the total area under this class. Other classes of artificial surfaces take up much smaller space (Table 1).

Comparing artificial areas with the total area of Bačka, it is concluded that they have an extremely low percent, ranging from $5.4 \%$ in 1990 to $5.9 \%$ in 2018 , i.e. from $482 \mathrm{~km}^{2}$ to $527.3 \mathrm{~km}^{2}$ (Figure 2). It is concluded that artificial areas had a constant increase in the share of the entire Bačka area between first and last Corine programs, which is an increase of $45.15 \mathrm{~km}^{2}$ and represents the largest increase of any category of land cover in the analyzed period.

This data can be used to evaluate the urbanization of the study area. When the data are presented cartographically, it is possible to see in which areas in Bačka urbanization was most intense and in which direction. It can be concluded that there was an increase in urban areas in all parts of Bačka (Figure 1). The most intensive expansion occurred 


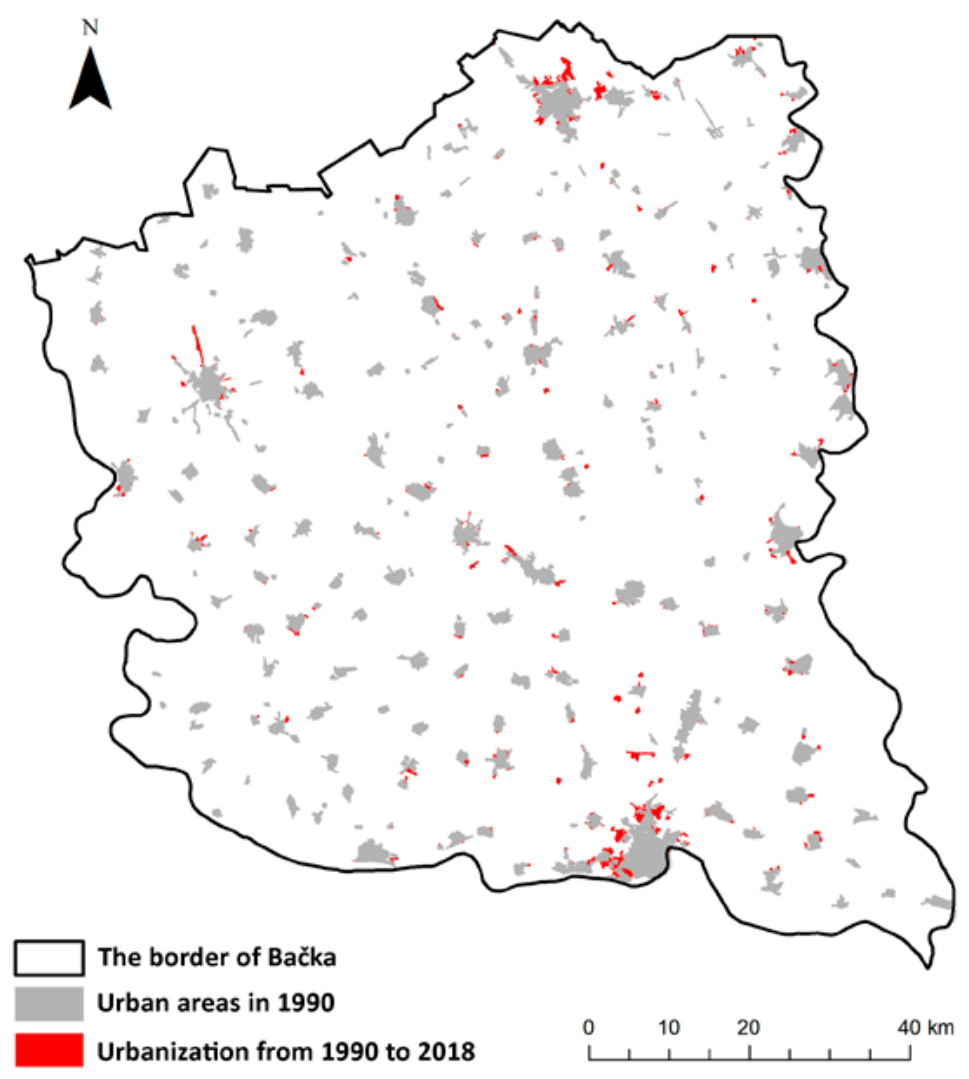

Figure 1. Urbanization of Bačka between 1990 and 2018

on the peripheries of major cities: Novi Sad, Subotica and Sombor. Rural areas have suffered minimal changes. In the districts of those small settlements that recorded an increase, this was mainly related to the increase of industrial units.

\section{Agricultural areas}

Arable land is the class of land cover that has the largest spatial coverage in Serbia. In 2006, this percentage was as high as $56.7 \%$ (Nestorov, Protić, 2009). Because Bačka is a highly agricultural region, this share is even larger, ranging from $84.9 \%$ in 2018 to $85.1 \%$ in 1990. Figure 2 show a decrease in territory under this class, which for the whole period amounted to $24.56 \mathrm{~km}^{2}$, which is the second largest decrease after the class of forests and semi-natural areas. This category of land cover in Bačka occurs in the following classes: Non-irrigated arable land (211), vineyards (221), fruit trees and berry plantations (222), pastures (231), complex cultivation patterns (242), and land principally occupied by agriculture with significant areas of natural vegetation (243). Non-irrigated arable land has the highest percent throughout the entire study period, with its percentage ranging from $90.5 \%$ in 1990 to $92.6 \%$ of all agricultural areas in 2018 . 


\section{Forest and semi-natural areas}

In Bačka, this class is represented by broad-leaved (311), coniferous forest (312), mixed forest (313), natural grassland (321) and transitional woodland/shrub (324). The percentage of these areas in Serbia is around 38\% (Nestorov, Protić, 2009), and in Bačka in the observed period it ranged from $6.5 \%$ in 2006 to $7 \%$ in 1990 . Such a large difference from the national percentage can be explained by the fact that in the past two centuries almost all natural land has been converted into arable land. The areas under this class ranged from $575.7 \mathrm{~km}^{2}$ to $622.1 \mathrm{~km}^{2}$. It is concluded that this class suffered the largest reductions from 1990 to 2018 of $46.25 \mathrm{~km}^{2}$.

As forests represent an extremely important category of land cover whose spatial changes would have to be considered separately in spite of their smaller share in the observed territory, in this paper this class will be divided into two: forests; and grass and shrub vegetation.

\section{Forests}

They represent a category of land cover, which, according to the most detailed level of Corine nomenclature, is divided into three classes: broad-leaved forest, coniferous forest and mixed forest. Broad-leaved forests are the most widespread in Bačka, accounting for $95 \%$ of all forests in this region. The area under forests is decreasing in the same trend as the whole class of natural areas. A sharp decline occurs from 1990 to 2006 (Figure 2) followed by a slight increase in these areas. The area under forests in Bačka ranges from $3.7 \%$ in 2006 to $4.2 \%$ in 1990 .

\section{Grass and shrub}

This, second part of the category of natural surfaces in Bačka throughout the studied years appears in two classes: natural grassland and transitional woodland/shrub. Class named dunes, beaches and sandy plains existed only in 1990 on an area of $0.1 \mathrm{~km}^{2}$. Transitional woodland/shrub accounts for $73.7 \%$ of this category in 1990 to $82.2 \%$ in 2018 . This class grew steadily over the observed period, while natural grasses declined. Spaces under grass and shrub have a different trend of movement as opposed to forests. They increase until 2000, after which their area declines until 2012, and has experienced a slight increase between the last two Corine programs.

\section{Wetlands}

Category of wetlands is represented in Bačka and the whole of Serbia by only one class: inland marshes (411). Of the five basic land cover classes according to Corine nomeclature, this class has the smallest spatial distribution. In Serbia, inland marshes cover $0.3 \%$ of the territory (Nestorov, Protić, 2009), while in Bačka this number is twice as high - from $0.5 \%$ in 1990 to $0.7 \%$ in 2018 . Wetlands are the class that suffered the largest increase in surface area after artificial surfaces, by $17.3 \mathrm{~km}^{2}$. 


\section{Water bodies}

Water bodies make the fifth and last category of the five basic categories of land cover. It is represented in Serbia and Bačka with two classes: water courses (511) and water bodies (512). The first consists of rivers, streams and canals, and the second consists of lakes, ponds and swamps. According to the spatial distribution, this type of land cover is in the penultimate place just above the wetlands with a share of $1.3 \%$ in Serbia (Nestorov, Protić, 2009), and in Bačka this number ranged from 1.96\% in 1990 to $2.09 \%$ in 2006. Observing the entire study period, this class increased its area by $8.22 \mathrm{~km}^{2}$. These areas increase until 2006, after which this number moderately decreases (Figure 2). Water courses account for $59.7 \%$ of this category in 2000 to $63.5 \%$ in 1990.
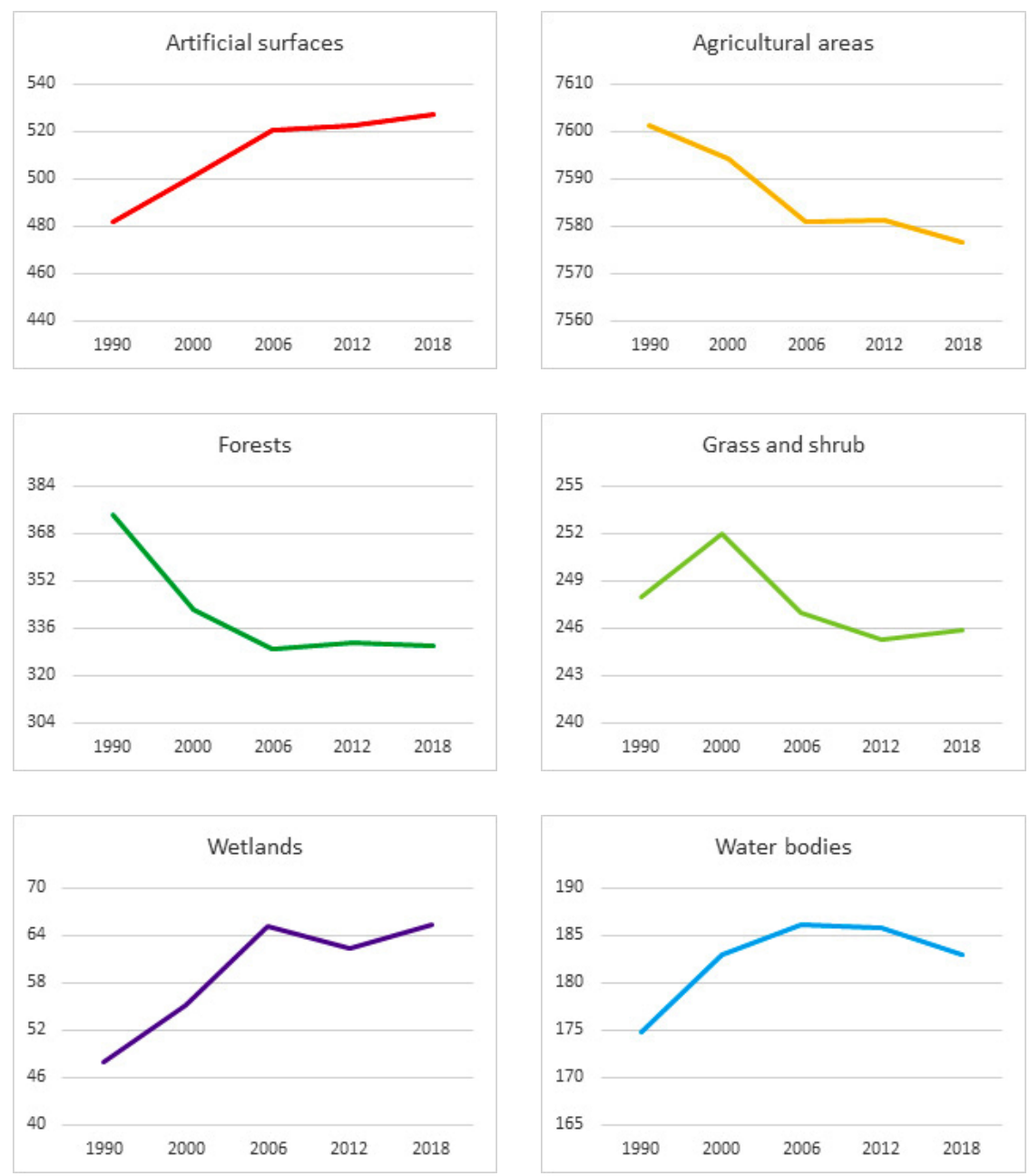

Figure 2. Change of basic classes of land cover in Bačka between 1990 and 2018 in km² 
Table 1. Corine Land Cover classes and its areas from 1990 to 2018 in km²

\begin{tabular}{|c|c|c|c|c|c|c|}
\hline \multicolumn{2}{|c|}{ Corine Land Cover class } & 1990 & 2000 & 2006 & 2012 & 2018 \\
\hline 111 & Continuous urban fabric & 0.3 & 0.3 & 0.3 & 0.3 & 0.3 \\
\hline 112 & Discontinuous urban fabric & 418.6 & 435.5 & 443.7 & 444.5 & 448.1 \\
\hline 121 & Industrial or commercial units & 46.7 & 47.1 & 56.2 & 56.7 & 58.3 \\
\hline 122 & Road and rail networks and associated land & 2.2 & 1.9 & 2.4 & 2.4 & 3.3 \\
\hline 123 & Port areas & 0.5 & 0.5 & 0.5 & 0.5 & 0.5 \\
\hline 124 & Airports & 0.7 & 0.0 & 0.0 & 0.0 & 0.0 \\
\hline 131 & Mineral extraction sites & 5.2 & 5.2 & 5.3 & 5.4 & 4.8 \\
\hline 132 & Dump sites & 0.25 & 0.84 & 1.82 & 2.09 & 2.86 \\
\hline 133 & Construction sites & 0.4 & 0.3 & 0.0 & 0.9 & 0.4 \\
\hline 141 & Green urban areas & 2.4 & 4.1 & 3.5 & 3.5 & 2.9 \\
\hline 142 & Sport and leisure facilities & 5.1 & 6.5 & 7.6 & 7.6 & 7.1 \\
\hline 211 & Non-irrigated arable land & 6879.4 & 6881.2 & 7014.0 & 7017.2 & 7015.3 \\
\hline 221 & Vineyards & 9.6 & 11.6 & 7.5 & 6.4 & 5.6 \\
\hline 222 & Fruit trees and berry plantations & 18.4 & 17.3 & 24.3 & 25.8 & 57.0 \\
\hline 231 & Pastures & 143.7 & 172.4 & 163.5 & 160.3 & 157.3 \\
\hline 242 & Complex cultivation patterns & 480.9 & 440.9 & 311.9 & 312.3 & 269.3 \\
\hline 243 & $\begin{array}{l}\text { Land principally occupied by agriculture, with } \\
\text { significant areas of natural vegetation }\end{array}$ & 69.2 & 70.8 & 59.5 & 59.4 & 72.0 \\
\hline 311 & Broad-leaved forest & 355.5 & 323.1 & 311.0 & 313.3 & 313.3 \\
\hline 312 & Coniferous forest & 6.7 & 6.3 & 4.9 & 4.6 & 3.3 \\
\hline 313 & Mixed forest & 11.9 & 12.9 & 12.9 & 12.9 & 13.5 \\
\hline 321 & Natural grassland & 62.5 & 42.3 & 46 & 44.1 & 43.7 \\
\hline 324 & Transitional woodland/shrub & 185.4 & 209.7 & 201.0 & 201.2 & 202.1 \\
\hline 331 & Beaches, dunes, and sand plains & 0.1 & 0.0 & 0.0 & 0.0 & 0.0 \\
\hline 411 & Inland marshes & 47.9 & 55.1 & 65.1 & 62.3 & 65.3 \\
\hline 511 & Water courses & 111.0 & 109.3 & 116.1 & 116.1 & 113.7 \\
\hline 512 & Water bodies & 63.5 & 59.7 & 62.3 & 62.5 & 62.1 \\
\hline
\end{tabular}

Since the period between the first two Corine recordings (1990-2000) is the longest and considers changes in land cover over a period of ten years, unlike all other programs during the study period that were carried out at intervals of six years, it was expected that this period brings the biggest changes (Figure 3). The reason is not only the longer period between two diameters, but also the social events that occurred during this period. This is mostly related to the civil war in the former Yugoslavia, which led to large emigrations of primarly Serb population from preset-day Republics of Croatia and Bosnia and Herzegovina. A large number of these people were accepted by Bačka as one of the closest territories to war events because of its western position in the country. Also, because of the poor economic and security situation between these two observing years, 
a number of people left the country and sought residency in one of the more developed European countries. These events caused, first and foremost, the expansion of urban areas, then abandonment and overgrowing of agricultural areas, and deforestation because of inflow of population, especially in the western part of Bačka where the need for wood in the form of heating and building materials has increased. The areas where the most spatial changes occurred are in the western Backka, in the alluvial plain of the Danube. Poylgons of changes also occur in the lower part of the Danube flow, near Novi Sad, then Subotica, Odžaci, on the Biserno ostrvo, southern parts of Potisje, etc. Parts of central and eastern Bačka remained unchanged during this period.
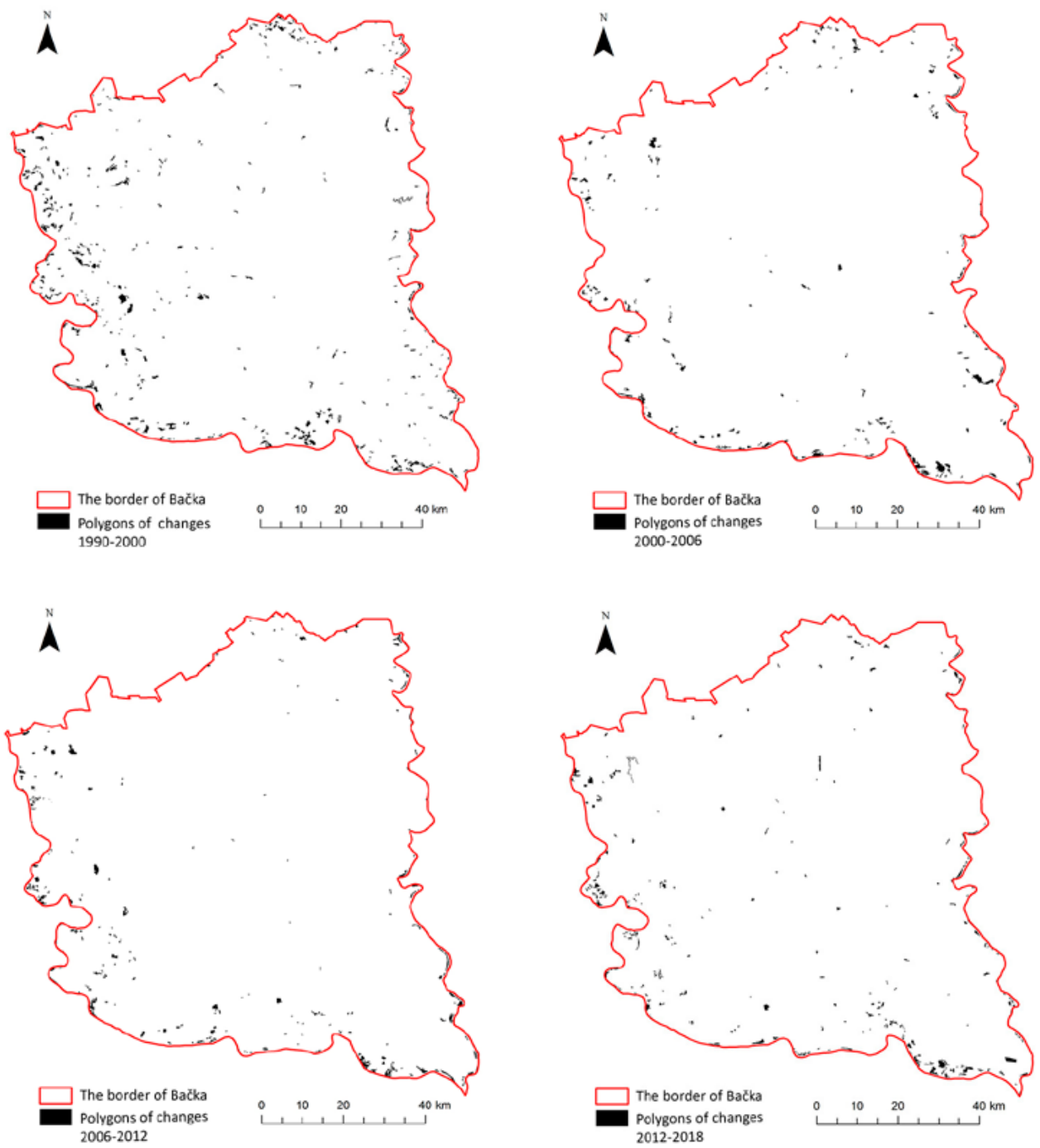

Figure 3. Polygons of changes occured between two Corine recordings 
Amoung the basic categories of land cover, the greatest reduction was suffered by forests, which lost as much as $31.8 \mathrm{~km}^{2}$ of their land. The following are agricultural areas that have reduced their distribution by $6.9 \mathrm{~km}^{2}$. Other categories increased their surface area, primarily artificial surfaces, which increased by $19.3 \mathrm{~km}^{2}$ (Figure 4 ).

Most changes in this period occurred in categories 211 - non-irrigated arable land, 311 - broad-leaved forest and 324 - transitional woodland/shrub. The change that affected the largest area was from broad-leaved forest to tranisitional woodland/shrub area, i.e. deforestation. These areas are represented by rivers, mostly in the northwestern part of Backa (Figure 5). The second in surface was the change of opposite direction - from the transitional vegetation to deciduous forest. It occurs in the same areas but on a much smaller scale. The next three changes in area are related to the loss of agricultural land (211) in favor of pastures (231), then transitional vegetation (324) and discontinuous urban areas (112). These data confirm that agricultural land has lost a large area and that it has been replaced by pastures, transitional woodland and shrub, and urban areas, speaks of their abandoned and expanding peripheries of large cities.

The shorter period between the two recordings and the more peaceful social events led to a smaller volume of spatial changes from 2000 to 2006 compared to the previous period. Looking at the Figure 3, it can be concluded that major changes were taking place in southern Bačka in the area of Koviljsko-petrovaradinski rit. Changes are also

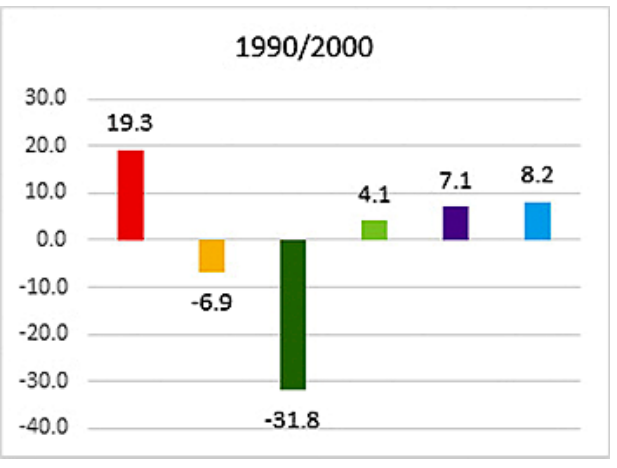

$2006 / 2012$

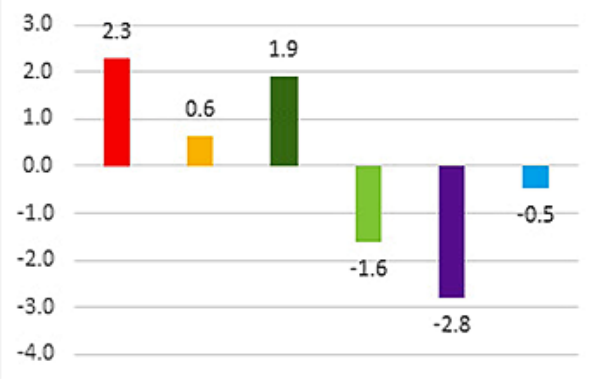

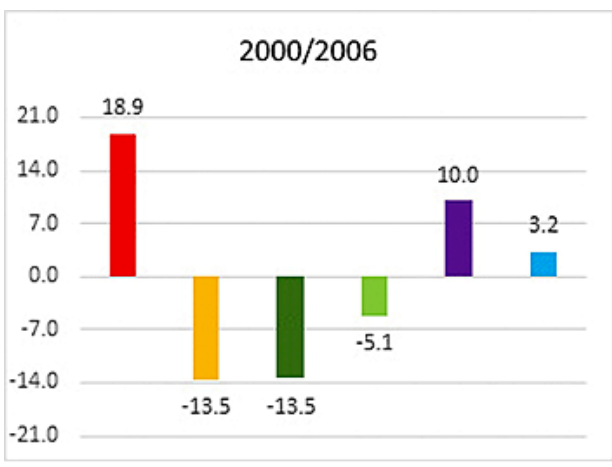

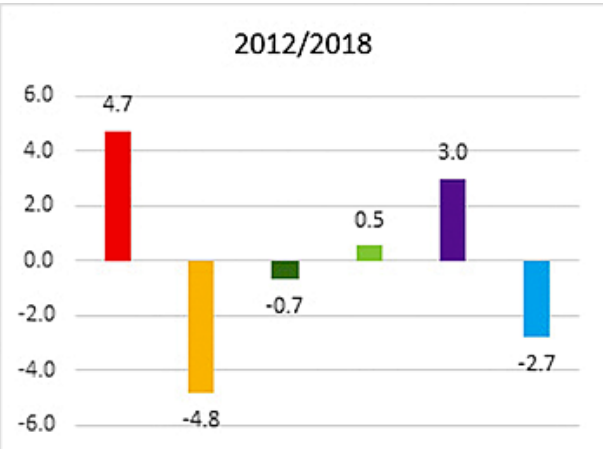

Figure 4. Change in surface of basic Corine Land Cover classes in $\mathrm{km}^{2}$ between two Corine recording (1. artificial, 2. agricultural, 3. forest, 4. grass and shrub,

5 . wetlands, 6 . water bodies) 
visible in the far north and northwest of Bačka. It is again part of central and eastern Bačka with no change of land cover class. This is due to the small number of inhabitants, the lack of large settlements, rivers and forested areas, as well as extremely high quality land that is not used for purposes other than agricultural.

The urbanization of Novi Sad, Subotica and Sombor is on a smaller scale, but it is still present. Urban areas also experienced the largest increase (Figure 4) of $18.9 \mathrm{~km}^{2}$. The second class of land cover by extension is wetlands that have expanded by as much as $10 \mathrm{~km}^{2}$. Forest and agricultural areas suffered the greatest reduction in this period $13.5 \mathrm{~km}^{2}$. These changes can be explained by the continued expansion of urban areas at the expense of agricultural, as well as the emergence of arable land in areas of forests, grass and shrubs. Illegal deforestation is certainly a major factor in reducing forest area. During this period, reduced agricultural land was influenced by the formation of artificial water reservoirs.

The major changes are also related to classes 211,311 and 324 as in the previous period. Again, the largest area was affected by the change from broad-leaved forest to the transitional woodland/shrub. This change occurred in northwestern and western Bačka in the alluvial plain of the Danube, then in southern Bačka on the same geomorphological unit, and also in northeastern Bačka - alluvial plain of the Tisa. The second change in surface is again the opposite direction one, and can be seen most in southern Bačka. Following are changes that take a completely different direction than between 1990 and 2000. Now there is an increase of 211 - non-irrigated arable land, which comes in the place of pastures, complex cultivation patterns and fruit trees and berry plantations (Figure 5). These changes are indicative of the revitalization of agricultural land after the period of their abandonment.

The third research period (2006-2012) shows the continuing decrease in the volume of spatial changes as we approach the present time and condition (Figure 3). This is the period with the least changes in land cover in the observed interval. The changes are again most prevalent in western and southern Bačka, along the Danube and lower flow of the river Tisa. During this interval, the urbanization processes of the largest cities decreased. The entire interior space of Bačka remained almost unchanged.

During this period, an increase in the area under forest of $1.9 \mathrm{~km}^{2}$ occurs for the first time, which is the second largest increase in this period after artificial surfaces that have expanded by $2.3 \mathrm{~km}^{2}$. This interval was marked by depopulation in Bačka, and there was no need for urban sprawl except in the two largest cites - Novi Sad and Subotica due to the high volume of village-city migrations. The increase in forests can be explained by continuous process of cutting-planting forest in PC "Vojvodinašume" where new trees are planted on the same sufaces after logging. This period is the first time that agricultural land has been increased too, by $0.6 \mathrm{~km}^{2}$. They originated mostly on natural grassland sites. Other land cover categories have reduced their range, the most wetlands losing $2.8 \mathrm{~km}^{2}$ of their land area. This was due to the drainage of wetlands and the formation of ponds in their place.

Although this is the first time the forest has been enlarged, the biggest change is again from class 311 to 324 , i.e. deforestation. The second change is from 324 to 311 , which covered only $3 \mathrm{~km}^{2}$ less. The third change by its surface was the change from ara- 
ble land to orchards. This is followed by the loss of water areas in favor of the transitional vegetation and natural grasses in favor of non-irrigated arable land.

The last period (2012-2018) brings significantly more changes than the previous one. The Figure 3 for this interval show much less changes in western Bačka, while the majority were in the area of Koviljsko-petrovaradinski rit. For the first time, major changes are observed in central Bačka.
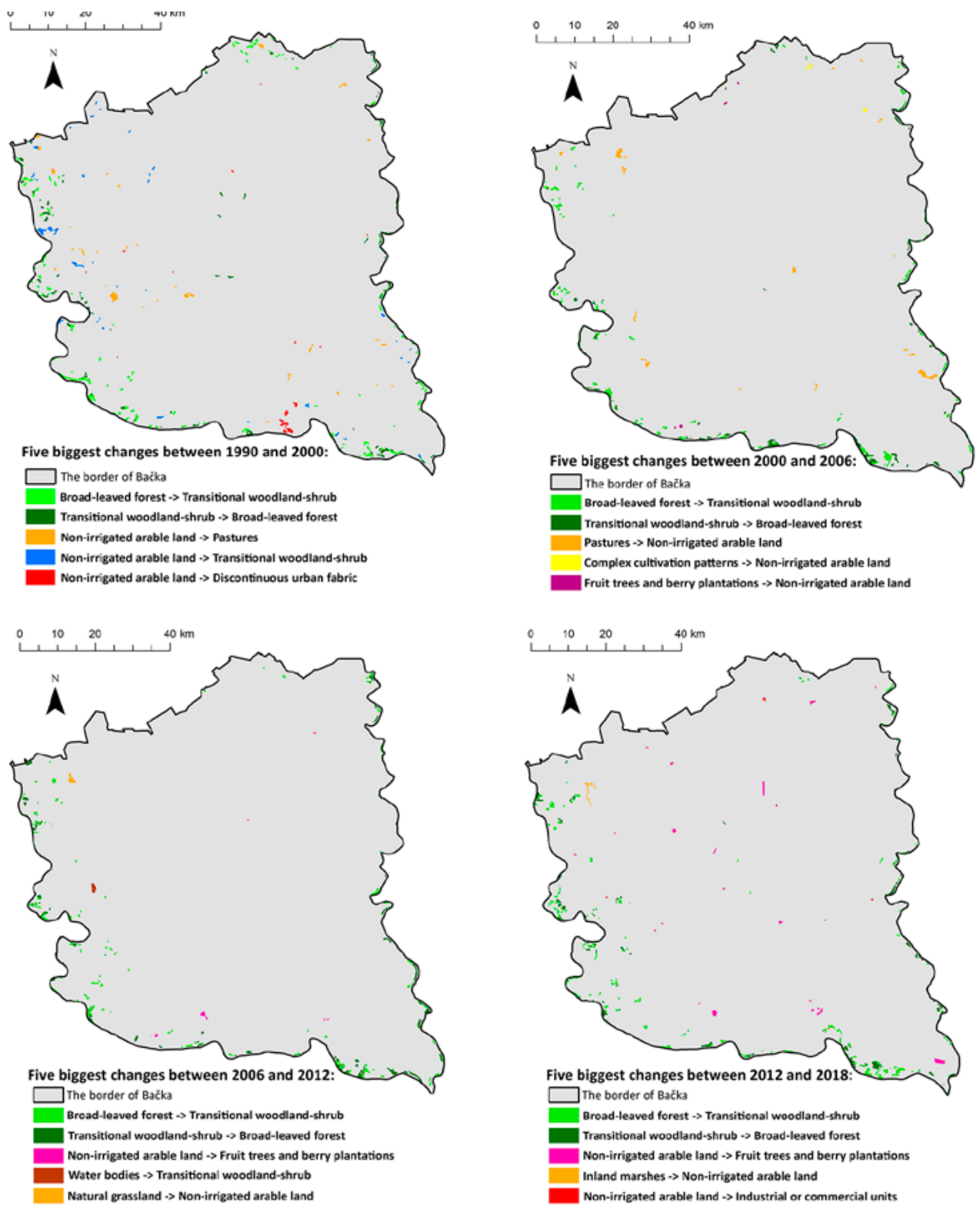

Figure 5. Five biggest changes in surface for each period between two Corine programs 
Urban areas $\left(4.7 \mathrm{~km}^{2}\right)$, wetlands $\left(3 \mathrm{~km}^{2}\right)$, and grass and shrubs $\left(0.5 \mathrm{~km}^{2}\right)$ suffered an increase. Other categories of basic land cover types reduce their area, the highest agricultural areas $\left(4.8 \mathrm{~km}^{2}\right)$. This large decrease in arable land in the period when no significant changes were expected was due to artificial surfaces. The increase in grass and shrubs is mainly due to the category of transitional woodland and shrub area occurring in deciduous forest areas. This change has hit the largest surface in this period as well. In the second place there is a change in the opposite direction, and both were happening in the area of southeast and west Bačka. As in the previous period, the third place is the increase of orchards this time by as much as $8.85 \mathrm{~km}^{2}$, which indicates the orientation of a large number of farmers to produce fruit instead of arable crops. This is followed by a change from wetlands to agricultural land, then from agricultural to industrial and commercial units (class 121). The emergence of this change on area of $1.18 \mathrm{~km}^{2}$ talks about the insistence of state policy on employment of people in industrial production.

\section{CONCLUSION}

The natural conditions that influenced the occurrence of certain types of land cover did not have a major impact on their changes from 1990 to 2018. The greatest impact on these changes was man. There were a total of 26 Corine land cover classes in the area of Bačka during this interval, 22 of which occur throughout the all observed years.

Artificial surfaces have been spreading throughout the period, and in particular they have been influenced by the class of discontinuous urban fabric and industrial and commercial units. These changes have mostly occurred on the peripheries of major cities such as Novi Sad, Subotica and Sombor. The largest area was covered by the class of agricultural areas with a share of over $80 \%$ in the total surface area of Bačka. They reduce their surface area throughout the period. The forests, mostly deciduous, suffered the greatest decrease in the observed period.

Spatial changes were most intense in the period from 1990 to 2000. This was mostly influenced by social circumstances, as a number of refugees from Croatia and Bosnia and Herzegovina settled this area, which resulted in the increase of urban areas and deforestation for the needs of building material and heating. The characteristic of this period is the abandonment of agricultural areas.

Between 2000 and 2006, the changes were much smaller and occurred near rivers or large cities. Urban areas suffered the greatest increase as a result of migration from villages to cities. During this period, there was pronounced degradation and increase of wetlands and water bodies.

The interval from 2006 to 2012 produced the least changes in the entire study period. Most changes occurred in the alluvial plain of the Danube. The intensity of urbanization has decreased. This is the only period when agricultural areas and forests increase, while the area of wetlands, and grass and shrubs has decreased. The pastures are converted to arable land, and the arable land in many parts of Bačka become plantations of fruit.

Spatial changes in the last analyzed period (2012-2018) were determined by the reductions in forests and agricultural areas, and a large increase in urban areas and wet- 
lands. One of the bigger tendencies is the transition from arable land to industrial and commercial units that shows an orientation towards employment in the industry.

Three regions of major spatial changes are distinguished. Western Bačka is the area that has undergone the greatest changes in the analyzed period, most influenced by man by changing the natural environment through the abandonment of arable land, deforestation and the formation and expansion of ponds. The second and third major change regions are the northeast and southeast Bačka. These two areas have large cities gravitating towards large number of people, which has influenced their expansion. The second part in these two regions is the changes of natural surfaces in the alluvial plain of the Tisa river and in Koviljsko-petrovaradinski rit where extensive declines in broad-leaved forests occurred in favor of the transitional woodland/shrub and grassy vegetation.

The parts with the least spatial changes are central and eastern Bačka. The reasons can be found in the absence of large cities and rivers. Small areas under forest and extremely high quality agricultural land that did not need to be used for other purposes.

In the next decade, the expansion of artificial areas around Novi Sad and Subotica can be expected to continue, in which a rage influx of population will create the need for the construction of new residential and industrial units. Further pressure on forest and agricultural land is projected, but at a lower intensity than in the period covered by this research.

\section{REFERENCES}

Bukurov, B. (1975). Fizičko-geografski problemi Bačke. Beograd: Srpska akademija nauka i umetnosti.

Bukurov, B. (1978). Bačka, Banat i Srem. Novi Sad: Matica Srpska.

Burgi, M., Hersperger, A., Scheneeberger, N. (2004). Driving forces of landscape change - current and new directions. Landscape ecology. Vol. 19, 857-868.

Davidović, R., Miljković, Lj., Ristanović, B. (2005). Reljef Bačke. Novi Sad: Prirodnomatematički fakultet. Departman za geografiju turizam i hotelijerstvo.

Grujić, N., Golubović, M., Jovanović, D. (2017). The use of satellite images in the field of agriculture. Zbornik radova Departmana za geografiju, turizam i hotelijerstvo, Vol. 47-1, 11-22.

Hansen, M., Potapov, P., Moore, R., Hancher, M., Turubanova, S., Tyukavina, A., Thau, D., Stehman, S., Goetz, S., Loveland, T., Kommareddy, A., Egorov, A., Chini, L., Justice, C., Townshend, J. (2013). High-Resolution Global Maps of 21st - Century Forest Cover Change. New York: Science. Vol. 324, 850-853.

Jovanović, D., Govedarica, M., Sabo, F., Bugarinović, Ž., Novović, O., Beker, T., Lauter, M. (2015). Land Cover change detection by using Remote Sensing - Case Study of Zlatibor (Serbia).Geographica Pannonica. Vol. 19, 162-173.

Kicošev, S., Bubalo-Živković, M., Ivkov, A. (2006). Stanovništvo Bačke. Novi Sad: Prirodno-matematički fakultet. Departman za geografiju, turizam i hotelijerstvo.

Lambin, E., Geist H. J. (2006). Land-Use and Land-Cover Change: Local Processes and Global Impacts. Berlin: Springer. 
Nestorov, I., Protić, D. (2009). CORINE kartiranje zemljišnog pokrivača u Srbiji. Beograd: Građevinska knjiga d.o.o.

Plieninger, T., Draux, H., Fagerholm, N., Bieling, C., Burgi, M., Kizos, T., Kuemmerle, T., Primdahl, J., Verburg, P. (2016). The driving forces of landscape change in Europe: A systematic review of the evidence. Land Use Policy. Vol. 57, 204-214.

Potić, I., Curčić N. B., Potić, M., Radovanović, M. M., Tretiakova, T. N. (2017). Remote sensing role in environmental stress analysis: East Serbia wildfires case study (20072017). Journal of the Geographical Institute "Jovan Cvijic", SASA. Vol. 67, Issue 3, 249264.

Popov, D., Marković, S., Jovanović, M., Mesaroš, M., Arsenović, D., Stankov, U., Deneš, G. (2012). Geomorphological Investigations and GIS approach of the Tamis loess plateau, Banat region (northern Serbia). Geographica Pannonica. Vol. 16, 1-9.

Popović, B., Jovanović, D. (2017). The use of remote sensing in arable land identification and mapping. Zbornik radova Departmana za geografiju, turizam i hotelijerstvo, Vol. 46-2, 96-104.

Samardžić-Petrović, M., Dragićević, S., Kovačević, M., Bajat, B. (2015). Modeling Urban Land Use Chnages Using Support Vector Machines. Transactions in GIS. Vol. 20. Stankov, U., Klaučo, M., Pavluković, V., Vujičić, M. D., Solarević, M. (2016). Assessing land-use chnages in tourism area on the example of Čajetina municipality (Serbia). Geographica Pannonica. Vol. 20, 105-113.

Subin, R. (1979). Razvitak poljoprivrede i savremene migracije stanovništva u Bačkoj. Glasnik srpskog geografskog društva. Vol. 2, Issue 59, 29-39.

Théau, J. (2012). Change detection. Berlin: Springer Handbook of Geographic Information. Springer Handbooks. 75-94

\section{Web pages}

https://land.copernicus.eu 